\title{
Zidovudine
}

\author{
R. Sperling* \\ Department of Obstetrics, Gynecology, and Reproductive Sciences, The Mount Sinai Medical Center, \\ New York, NY
}

KEY WORDS

antiretroviral regimens; HIV-1 infection; mother-to-child HIV-1 transmission

Z idovudine (Retrovir ${ }^{\mathrm{TM}}$ ) is one of the best known agents used in the treatment of women with human immunodeficiency virus type-1 (HIV1) infection. This generally well-tolerated agent has become a mainstay for the prevention of mother-to-child HIV-1 transmission and is often a component of combination antiretroviral regimens utilized for the treatment of both adult and pediatric HIV-1 infected individuals.

\section{STRUCTURE AND DERIVATION}

Zidovudine (ZDV,AZT, 3'-azido-3'-deoxythymidine) is a synthetic nucleoside analogue of a naturally occurring nucleoside, thymidine, in which the $3^{\prime}$-hydroxy (-OH) group is replaced by an azido $\left(-\mathrm{N}_{3}\right)$ group (Fig. 1).

\section{MECHANISM OF ACTION}

Zidovudine (ZDV,AZT) is one of a class of human immunodeficiency virus type-1 (HIV-1) antiviral agents known as dideoxynucleoside reverse transcriptase inhibitors (NR'TIs). ZDV inhibits HIV-1 reverse transcriptase, the enzyme needed to catalyze the synthesis of proviral double-stranded DNA from the RNA template (Fig. 2), and therefore interferes with a critical step in the HIV viral life cycle. The antiviral activity of ZDV depends on the intracellular conversion of the drug to a triphosphate metabolite and requires intracellular host cell kinases for conversion to this active $5^{\prime}$ triphosphate form. The active $5^{\prime}$-triphosphate has an affinity for HIV reverse transcriptase and competes with endogenous triphosphate nucleotides for incorporation into the newly synthesized proviral DNA. ZDV triphosphate lacks a free $3^{\prime}$-hydroxyl group. In order for nucleic acid replication to occur, the 3'-hydroxyl of a naturally occurring nucleoside is the acceptor for covalent attachment of subsequent nucleosides 5'-monophosphate. When ZDV triphosphate is incorporated, it acts as a chain terminator preventing further elongation of the viral DNA chain.

In addition to $\mathrm{ZDV}$, the other NRTIs that are approved by the Food and Drug Administration (FDA) are didanosine (ddI), zalcitibine (ddC), stavudine (d4T), and lamivudine (3TC). Although the structure and mechanism of action of all the nucleoside analogues are similar, they differ significantly in their intracellular phosphorylation pathways and kinetics, which contribute to differences in their in vitro antiretroviral activity and pattern of toxicities. The NRTIs have a wider spectrum of antiviral activity than the other available HIV-1 antiviral agents. Other classes of antiviral agents that have been approved by the FDA for the treatment of HIV disease are non-nucleoside reverse transcriptase inhibitors (NNRTIs), which include nevirapine and delaviridine, and the HIV protease inhibitors which include ritonavir, saquinavir, indinavir, and nelfinavir. HIV protease inhibitors have greater activity than either NRTIs or NNR'TIs against $\mathrm{HIV}-1$; these compounds were specifically designed based on the structure of the HIV protease enzyme and have a spectrum of activity limited to HIV-1 and to a lesser extent HIV-2.

*Correspondence to: R. Sperling, MD, Department of Obstetrics, Gynecology, and Reproductive Sciences, The Mount Sinai Medical Center, Box 1173, One Gustave L. Levy Place, New York, NY 10029-6574. E-mail: rsperling@smtplink.mssm.edu 
<smiles>Cc1cn(C2CC(N)C(O)O2)c(=O)[nH]c1=O</smiles>

Fig. I. Structure of zidovudine (ZDV,AZT, 3'-azido-3'deoxythymidine).

\section{PHARMACOKINETICS}

Zidovudine is rapidly absorbed by the gastrointestinal tract following oral administration with peak serum concentrations occurring within 0.4-1.4 hours. Absorption shows considerable interindividual variation and is influenced by the time and content of the last meal. Once absorbed, prior to systemic distribution, zidovudine undergoes significant first-pass metabolism, giving an average bioavailability of $63 \%$. Zidovudine is approximately $25 \%$ protein bound, primarily to albumin. Zidovudine distributes into cells by passive diffusion and is relatively lipophilic; it can be detected in fluids other than plasma, which contributes to its large distribution volume. Zidovudine is primarily metabolized by liver through hepatic $5^{\prime}$-glucuronidation, forming a stable glucuronidated metabolite (GZDV) that is excreted by the kidneys. Approximately $14-20 \%$ of unchanged drug and 60 $70 \%$ of its major metabolite are excreted in the urine following oral or intravenous administration. ${ }^{1}$

Administration of the same standard dose of oral zidovudine results in a variable plasma concentration among adults. The variability is a consequence of between-patient differences in the absorption, distribution, metabolism, and clearance of the drug. ${ }^{1}$ Although the plasma pharmacokinetic characteristics have been well studied, the therapeutic range of $\mathrm{ZDV}$ and the importance of intracellular pharmacokinetics are not completely understood. Therefore, the optimal dosing strategy for ZDV has not been determined. Recommended doses (see Table 1) are based on clinical endpoints, and not on pharmacodynamic considerations.
Pharmacokinetics in pregnancy have been studied. $^{2-4}$ ZDV and GZDV have been detected in the fetus, amniotic fluid, and breast milk. Transplacental transfer of ZDV is by passive diffusion, ${ }^{5}$ therefore, maternal plasma concentrations will be a major determinant of fetal concentrations. ${ }^{6,7}$ Pregnancy introduces additional sources of variability in the plasma drug concentration, including changes in volume of distribution (expanded plasma volume, increased adipose tissue and the addition of a fetal compartment), changes in drug clearance (increase in cardiac output and a concomitant increase in renal blood flow), and increases in hepatic metabolism. Preliminary reports of zidovudine disposition in obese pregnant women found that achievable plasma concentrations were far lower than expected based on population pharmacokinetic information. ${ }^{8}$ In addition, information from the AIDS (acquired immunodeficiency syndrome) Clinical Trial Group (ACTG) 076 study suggests that maternal obesity may be a risk factor for the failure of ZDV prophylaxis to prevent perinatal HIV-1 transmission. (R. Sperling, personal communication)

\section{CLINICAL APPLICATIONS (DEMONSTRATED EFFICACY) Treatment of Adult Patients}

Zidovudine has been extensively studied in the treatment of patients with HIV infection whose CD4+ cell counts are $\leq 500$ cells $/ \mathrm{mm}^{3}$. In initial studies, ZDV reduced the risk of disease progression, opportunistic infections, and death in patients with advanced HIV disease. ${ }^{9}$ Further experience with the drug revealed that the clinical benefits of ZDV monotherapy were not sustained over the long term. Recent studies have shown that the use of ZDV as part of a combination antiretroviral regimen results in suppression of viral replication and greater clinical benefits, including survival outcome, when compared with ZDV alone. ${ }^{10}$

\section{Prevention of Mother-to-Child HIV-I Transmission}

In February 1994, the National Institutes of Health (NIH)-sponsored ACTG 076 study was closed to enrollment and unblinded when an interim analysis demonstrated that a regimen that combined maternal and newborn ZDV could dramatically reduce the risk of mother-to-infant HIV-1 transmission. ${ }^{11}$ 


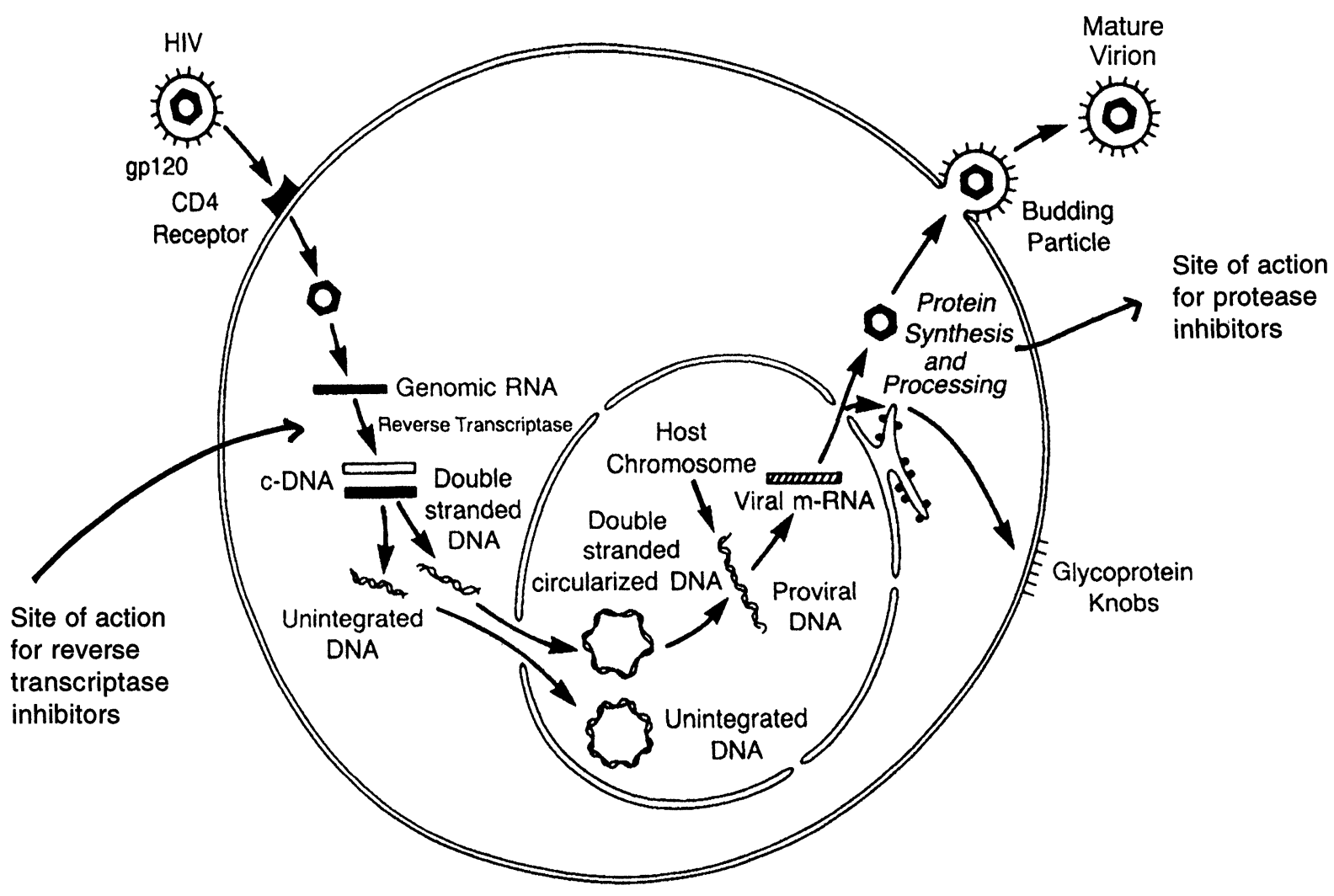

Fig. 2. Life cycle of HIV.

The availability of a regimen that could reduce the transmission of a fatal pediatric disease led the United States Public Health Service ${ }^{12}$ to develop consensus guidelines for clinicians about the use of ZDV during pregnancy. Since implementation of these guidelines, additional information about the efficacy of ZDV for the prevention of perinatal transmission has become available.

In November 1996, an efficacy update from the ACTG 076 study confirmed the interim findings. The original report was a Kaplan-Meier estimate of the transmission risk and was based on 363 motherinfant pairs. The recent update included 402 mother-infant pairs, all of whom had completed the 18-month infant follow-up; the rate of HIV-1 transmission was $7.6 \%$ with $\mathrm{ZDV}$ treatment and $22.6 \%$ with placebo $(P=<.001) .{ }^{13}$

In March 1997, enrollment in another pediatric ACTG study, Protocol 185, was stopped due to an unexpectedly low transmission rate in both study arms. ${ }^{12}$ The ACTG 185 was a randomized, controlled clinical trial which compared HIVIG (an immunoglobulin preparation containing high levels of antibodies to HIV) to IVIG (standard immunoglob- ulin) to determine whether HIVIG could further reduce the risk of mother-to child transmission if it was added to the maternal-child $\mathrm{ZDV}$ regimen successfully utilized in ACTG 076. The ACTG 185 study was designed for women with more advanced immunosuppression than the 076 study. In ACTG 076, all women had CD4+ T-cell counts exceeding 200 cells $/ \mathrm{mm}^{3}$, and only $5 \%$ had received any prior ZDV; in contrast, in ACTG 185, 23\% had baseline CD4+ cell counts less than 200 cells $/ \mathrm{mm}^{3}$, and $21 \%$ of women had received prior ZDV. After analyzing outcomes in 379 infants, the estimated overall rate of mother-to-infant HIV transmission was $4.8 \%$ with no difference between HIVIG and IVIG recipients. ${ }^{14}$ The utility of prophylactic ZDV in pregnant women with advanced immunosuppression that was demonstrated in ACTG 185 is consistent with other reports. ${ }^{15,16}$

In February 1998, enrollment in a trial conducted by the Ministry of Public Health of Thailand (in collaboration with the Centers for Disease Control and Prevention [CDC]) was stopped when an interim analysis demonstrated the success of a short-course of maternal antepartum/intrapartum 
TABLE I. Zidovudine dosing considerations

\begin{tabular}{|c|c|c|c|c|c|c|}
\hline Medication & $\begin{array}{l}\text { Mode of } \\
\text { action }\end{array}$ & $\begin{array}{c}\text { Dosage } \\
\text { form }\end{array}$ & Dosing & $\begin{array}{l}\text { Major } \\
\text { toxicities }\end{array}$ & $\begin{array}{c}\text { Drug } \\
\text { interactions }\end{array}$ & $\begin{array}{c}\text { Pregnancy } \\
\text { considerations } \\
\end{array}$ \\
\hline $\begin{array}{l}\text { Zidovudine } \\
\text { (AZT, ZDV, } \\
\text { Retrovir) }\end{array}$ & $\begin{array}{l}\text { Nucleoside } \\
\text { reverse } \\
\text { transcriptase } \\
\text { inhibitor } \\
\text { (NRTI) }\end{array}$ & $\begin{array}{l}100 \mathrm{mg} \text { capsules } \\
300 \mathrm{mg} \text { tablets } \\
\text { Syrup: } 50 \\
\mathrm{mg} / \mathrm{ml} \mathrm{IV}: 10 \\
\mathrm{mg} / \mathrm{ml} \\
\text { Also available in } \\
\text { combination } \\
\text { with } 3 \mathrm{TC} \text {. } \\
\text { (Combvir-AZT } \\
300 \mathrm{mg} / 3 \mathrm{TC} \\
150 \mathrm{mg} \text { ) }\end{array}$ & $\begin{array}{l}\text { Adults: } \\
100 \text { mg orally } 5 \\
\text { times per day } \\
\text { (dose studied } \\
\text { in perinatal } \\
\text { prevention } \\
\text { trials) } \\
200 \text { mg orally } 3 \\
\text { times per day } \\
300 \text { mg orally } \\
\text { twice a day } \\
\text { Intravenous in } \\
\text { labor: } 2 \text { mg/kg } \\
\text { loading dose, } \\
\text { followed by } \\
\text { continuous } \\
\text { infusion of } 1 \\
\text { mg/kg/hr } \\
\text { Intravenous } \\
\text { newborn } \\
\text { intermittent } \\
\text { infusion: } 1.5 \text { mg/kg } \\
\text { every } 6 \text { hours } \\
\text { Pediatrics: } \\
90-180 \text { mg/m } 2 \\
\text { orally every } \\
6-12 \text { hr } \\
\text { Special } \\
\text { considerations: } \\
\text { Dose interruption } \\
\text { for severe } \\
\text { anemia or } \\
\text { granulocytopenia }\end{array}$ & $\begin{array}{l}\text { Most frequent: } \\
\text { Bone marrow } \\
\text { suppression } \\
\text { (anemia and } \\
\text { granulocytopenia) } \\
\text { Nausea, myalgias, } \\
\text { headaches, and } \\
\text { insomnia are } \\
\text { common and } \\
\text { diminish over } \\
\text { time } \\
\text { Less frequent: } \\
\text { Long-term } \\
\text { administration } \\
\text { has been } \\
\text { associated with } \\
\text { peripheral } \\
\text { myopathy } \\
\text { Marked elevations } \\
\text { in liver function } \\
\text { tests, } \\
\text { hepatomegaly, } \\
\text { and lactic } \\
\text { acidosis } \\
\text { secondary to } \\
\text { steatosis has } \\
\text { been reported } \\
\end{array}$ & $\begin{array}{l}\text { Co-administration } \\
\text { with } \\
\text { ganciclovir, } \\
\text { alpha-interferon, } \\
\text { dapsone, } \\
\text { flucytosine, or } \\
\text { vincristine can } \\
\text { increase } \\
\text { hematologic } \\
\text { toxicity } \\
\text { Phenytoin and } \\
\text { fluconazole can } \\
\text { effect ZDV } \\
\text { levels }\end{array}$ & $\begin{array}{l}\text { Category: C } \\
\text { Transplacental } \\
\text { passage: yes } \\
\text { Animal safety: high } \\
\text { doses during } \\
\text { late gestation } \\
\text { associated with } \\
\text { transplacental } \\
\text { carcinogenicity } \\
\text { in mice } \\
\text { Human safety: } \\
\text { extensive } \\
\text { experience; } \\
\text { reversible } \\
\text { anemia in the } \\
\text { newborn; } \\
\text { long-term } \\
\text { safety is being } \\
\text { studied } \\
\text { Follow-up of } \\
\text { children } \\
\text { exposed in } \\
\text { utero is } \\
\text { recommended }\end{array}$ \\
\hline
\end{tabular}

zidovudine therapy for the prevention of motherto-child HIV-1 transmission. ${ }^{17}$ When ZDV, $300 \mathrm{mg}$ twice daily, was given from 36 weeks of gestation until the onset of labor and then increased to 300 $\mathrm{mg}$ orally every three hours in labor, the transmission rate was decreased by $51 \%$; the Kaplan-Meier estimates of transmission risk were $9.2 \%$ in the placebo group and $18.6 \%$ in the placebo group, $P=$ 0.008 . These findings are consistent with observational studies in the United States ${ }^{15,16}$ and provide substantial scientific support for using shorter courses of zidovudine when the complete 076 regimen cannot be given.

Results of all three clinical trials are consistent with the mounting epidemiologic evidence supporting the use of ZDV regimens to prevent mother-to-child HIV-1 transmission:
TABLE 2. Zidovudine regimen studied in ACTG 076

\begin{tabular}{|c|c|c|}
\hline $\begin{array}{l}\text { Antepartum } \\
\text { dose }\end{array}$ & $\begin{array}{c}\text { Intrapartum } \\
\text { dose }\end{array}$ & $\begin{array}{c}\text { Newborn } \\
\text { dose }\end{array}$ \\
\hline $\begin{array}{l}100 \text { mg orally } 5 \\
\text { times a day, } \\
\text { initiated between } \\
14 \text { and } 34 \text { weeks } \\
\text { of gestation and } \\
\text { continued until } \\
\text { labor }\end{array}$ & $\begin{array}{l}2 \mathrm{mg} / \mathrm{kg} \text { loading } \\
\text { dose, followed } \\
\text { by continuous } \\
\text { infusion of I } \\
\mathrm{mg} / \mathrm{kg} / \mathrm{hr}\end{array}$ & $\begin{array}{l}2 \mathrm{mg} / \mathrm{kg} \text { orally every } \\
\text { hours, initiated } \\
\text { within } 8-12 \text { hours } \\
\text { of birth and } \\
\text { continued for } 6 \\
\text { weeks }\end{array}$ \\
\hline
\end{tabular}

- Nationwide, the number of cases of pediatric AIDS reported to the CDC declined $47 \%$ between 1992 and 1996. ${ }^{18}$

- In North Carolina, mother-to-child transmission rates have decreased from $21 \%$ in 1993 to $6 \%$ in 1996 following the use of ZDV. ${ }^{19}$ 
- In New York City, in a cohort of 898 children followed between July of 1994 and June of 1996, the transmission rate was $13 \%$ in those motherinfant pairs who received any $\mathrm{ZDV}$, compared with $26 \%$ in mother-infant pairs who received no ZDV. ${ }^{20}$

- In New York State, an observational study of 943 HIV-exposed infants born after August 1995 found a transmission rate of $6.3 \%$ among infants exposed to the full 076 regimen, an $11.5 \%$ transmission rate among infants exposed to $\mathrm{ZDV}$ starting either in labor or in the immediate neonatal period, and a $26.5 \%$ transmission rate among infants who received no ZDV prophylaxis. ${ }^{21}$ This is the first report that supports the efficacy of intrapartum/newborn regimens and even newborn regimens alone if initiated within 48 hours of birth.

\section{ZDV MECHANISM OF ACTION AS CHEMOPROPHYLAXIS}

At the time of the interim ACTG 076 study analysis, the mechanism by which $\mathrm{ZDV}$ reduced the risk of transmission was unknown. ${ }^{11}$ It is now known, through analysis of viral loads in maternal plasma samples from entry and delivery, that ZDV appears to act primarily by a mechanism other than the reduction of maternal viral burden. Neither the change in maternal plasma viral load from entry to delivery nor a critical level at delivery fully accounts for the substantially reduced transmission rate observed in the ZDV treated group. The possibility of a significant prophylactic effect in utero and/or intrapartum (both during and after exposure) has been raised.

\section{Side Effects}

\section{Drug Toxicities in Adult Trials}

Early studies utilizing $1200 \mathrm{mg} / \mathrm{d}$ reported significant patient problems with drug-associated toxicities. Later studies demonstrated the efficacy of 500-600 mg/d with significantly reduced toxicity. The major side effects include anemia and/or granulocytopenia, headache, fatigue, malaise, nausea, and other gastrointestinal discomforts. Longterm ZDV therapy has been associated with myopathy and rare cases of hepatic steatosis and lactic acidosis.

\section{Drug Toxicities in Perinatal Transmission Trials}

There remains ongoing concerns about the safety of the 076 regimen, both for the mother and for the infant. Specific questions have been raised regarding adverse effects of this regimen on the longterm health of uninfected infants and on maternal disease progression.

The only infant toxicity associated with the AC'TG 076 regimen has been a mild, reversible anemia whose nadir has been at 6 weeks of age with resolution by 12 weeks of age. Infant anemia was not associated with the duration of maternal zidovudine treatment. Among uninfected infants in the AC'TG 076 study, there were no differences between the zidovudine-exposed infants and the placebo infants in growth patterns, immunologic parameters (lymphocyte subsets), or the occurrence of childhood neoplasias. ${ }^{22}$ The Antiretroviral Pregnancy Registry, a collaborative prospective registry supported by pharmaceutical manufacturers, has not found an association between $\mathrm{ZDV}$ exposure and congenital anomalies among the cases that have been reported to date. ${ }^{23}$

There is no standard battery of safety tests in animals that are required before a drug is approved by the FDA for use in humans. Although animal testing is frequently performed to assess pregnancy safety, animal data may be difficult to interpret and may not accurately predict risks to human pregnancy. Safety concerns about the use of $\mathrm{ZDV}$ in pregnancy have included concerns about potential transplacental carcinogenicity. Theoretically, nucleoside analogs such as ZDV can interfere with DNA synthesis and are potential carcinogens. In one rodent model, high doses of zidovudine given during pregnancy were not associated with adverse outcomes in offspring, including the development of tumors. ${ }^{24}$ In another model, extremely high doses of zidovudine administered during pregnancy were associated with an increased risk of tumors in offspring. ${ }^{25}$ An NIH panel comprised of clinicians, scientists, and patient advocates reviewed all available animal data and unanimously concluded that the benefits of zidovudine in reducing perinatal HIV far outweighed the potential risks. Other recommendations of this panel included the need to inform women of these data, to conduct long-term follow-up on all children ex- 
posed in-utero to $\mathrm{ZDV}$, and to conduct more clinical and basic research on the topic.

In ACTG 076, at 6 months postpartum, there were no differences in clinical, immunologic, or virologic disease progression between those women who received the $076 \mathrm{ZDV}$ regimen and those who received placebo. ${ }^{20}$

\section{ZDV Resistance}

Monotherapy with antiretroviral agents has been associated with drug resistance. Drug resistance is more likely to emerge with increasing duration of therapy and with advancing immunosuppression. In the ACTG 076 study, maternal therapy was not associated with the development of high level zidovudine resistance. ${ }^{26}$

\section{Cost}

ZDV is available in a variety of different formulations ('Table 1). Based on average wholesale prices, the unit cost of the $100-\mathrm{mg}$ capsule is $\$ 1.59$, the unit cost of the $300-\mathrm{mg}$ tablet is $\$ 4.78$, and the unit cost of a $200-\mathrm{mg}$ bottle for intravenous injection is $\$ 17.30$. Cost-effectiveness analyses have estimated that the ZDV drug cost per treated case following the AC'TG 076 regimen is $\$ 895 .^{27}$

\section{SUMMARY}

Zidovudine was the first agent approved for treatment of HIV disease, and since its widespread availability in 1987, the pharmacokinetic disposition and clinical effects of ZDV have been extensively evaluated. In addition to its utility as a component of a multidrug combination regimen for the treatment of adult and pediatric HIV-1 infection, it is the only agent approved by the FDA for the prevention of mother-to-child HIV-1 transmission.

The effectiveness of $\mathrm{ZDV}$ for the prevention of mother-to-child HIV-1 transmission has been demonstrated in several studies. The optimal time during gestation to initiate ZDV therapy and the relative importance of the intrapartum and newborn components is the focus of both current interventional and observational studies. Until more information is available from these trials, the combined maternal/newborn ZDV regimen studied in ACTG 076 remains the recommended treatment regimen of choice in the United States.

\section{REFERENCES}

1. Acosta EP, Page LM, Fletcher CV: Clinical pharmacokinetrics of zidovudine. An update. Clin Pharmacokinet 30:251-262, 1996.

2. O'Sullivan MJ, Boyer PJJ, Scott GB, et al.: The pharmacokinetics and safety of zidovudine in the third trimester of pregnancy for women infected with human immunodefiency virus and their infants: phase 1 acquired immundodeficiency syndrome clinical trials group (protocol 082) Zidovudine Collaborative Working Group. Am J Obstet Gynecol 168:1510-1516, 1993.

3. Watts DH, Brown Z, Tartaglione T, et al.: Pharmacokinetic disposition of zidovudine during pregnancy. J Infect Dis 163:226-232, 1991.

4. Sperling RS, Roboz J, Dische R, Silides D, Holzman I, Jew E: Zidovudine pharmacokinetics during pregnancy. Am J Perinatol 9:247-249, 1992.

5. Liebes I, Mendoza S, Wilson D, Dancis J: Transfer of zidovudine (AZT) by human placenta. J Infect Dis 161: 203-207, 1990.

6. Krauer B, Krauer F, Hytten FE: Drug disposition and pharmacokinetics in the maternal-placental fetal unit. Pharmacol Ther 10:301-328, 1990.

7. Reynolds F, Knott C: Pharmacokinetics in pregnancy and placental drug transfer. Oxf Rev Reprod Biol 11: 389-449, 1989.

8. Acosta EP, Schwebke K, Henry K, Fletcher CV: Disposition of zidovudine in obese pregnant women with human immunodeficiency virus type-1 infection [letter]. J Infect Dis 174:673, 1996.

9. Fischl MA, Richman DD, Grieco MH, et al.: The efficacy of azidothymidine (AZT) in the treatment of patients with AIDS and AIDS-related complex: a doubleblind, placebo-controlled trial. N Engl J Med 317:185191, 1987.

10. Carpenter CJ, Fischl MA, Hammer SM, et al.: Antiretroviral therapy for HIV infection in 1988; updated recommendations of the International AIDS Society-USA Panel. JAMA 280:78-86, 1998.

11. Connor EM, Sperling RS, Gelber RD, et al.: Reduction of maternal-infant transmission of human immunodeficiency type 1 with zidovudine treatment. N Engl J Med 311:1173-1180, 1994.

12. Centers for Disease Control and Prevention: Recommendations for the use of zidovudine to reduce perinatal transmission of human immunodeficiency virus. Morb Mortal Wkly Rev 43(RR-11):1-19, 1994.

13. Sperling RS, Shapiro DE, Coombs RW, et al.: Maternal viral load, zidovudine treatment, and the risk of transmission of human immunodeficiency virus from mother to infant. N Engl J Med 335:1621-1629, 1996.

14. Pediatric ACTG Protocol 185 Executive Summary: National Institute of Child Health and Human Development. Bethesda, MD: March 25, 1997.

15. Frenkel LM, Wagner LE, Demeter LM, et al.: Effects of zidovudine use during pregnancy on resistance and mother-to-child transmission of human immunodeficiency virus type 1. Clin Infect Dis 20:1321-1326, 1995. 
16. Matheson PB, Abrams EJ, Thomas PA, et al.: Efficacy of antenatal zidovudine in reducing perinatal transmission of human immunodeficiency virus type 1 . J Infect Dis 172:353-358, 1995.

17. Centers for Disease Control and Prevention: Administration of zidovudine during late pregnancy and delivery to prevent perinatal HIV transmission-Thailand, 19961998. Morb Mortal Wkly Rev 47:151-154, 1998.

18. Centers for Disease Control and Prevention: Update: Perinatally acquired HIV/AIDS - United States, 1997. Morb Mortal Wkly Rev 46:1086-1092, 1997.

19. Fiscus SA, Adimora AA, Schoenbach VJ, et al.: Perinatal HIV infection and the effect of zidovudine therapy on transmission in rural and urban counties. JAMA 275: 1483-1488, 1996.

20. Bornschlegel K, Thomas $P$, Brooks A, et al.: Impact of zidovudine on perinatal HIV transmission in New York City. (Abstract). A Conference on Global Strategies for the Prevention of HIV Transmission from Mothers to Infants. September 3-6, 1997; Washington, DC.

21. Birkhead G, Warren BL, Charbonneau TT, et al.: Evidence for intermediate rates of perinatal transmission with partial 076 regimen: Results of an observational study. (Abstract \#244). 5th Conference of Retroviruses and Opportunistic Infections. February 1-5, 1998; Chicago, IL.
22. Sperling RS, Shapiro DE, McSherry GD, et al.: Safety of the maternal-infant zidovudine regimen utilized in the Pediatric AIDS Clinical Trial Group 076 study. AIDS 12:1805-1813, 1998.

23. Antiretroviral Pregnancy Registry: Interim report for 1 January 1989 through 31 December 1996. A collaborative project managed by Bristol-Myers Squibb Co., Glaxo Wellcome, Hoffman-LaRoche Inc., and Merck \& Co., Inc.

24. Ayers KM, Torrey CE, Reynolds DJ: A transplacental carcinogenicity bioassay in Cd-1 mice with zidovudine. Fundam Appl Toxicol 38:195-198, 1997.

25. Olivero OA, Anderson LM, Diwan BA, et al.: AZT is a genomic transplacental carcinogen in animal models. J AIDS 14:A29(abstract 52), 1997.

26. Eastman PS, Shapiro DE, Coombs RW, et al.: Maternal viral genotypic zidovudine resistance and infrequent failure of zidovudine therapy to prevent perinatal transmission of human immunodeficiency virus type- 1 in pediatric AIDS Clinical Trials Group protocol 076. J Infect Dis 177:557-564, 1998.

27. Mauskopf JA, Paul JE, Wichman DS, White AD, Tilson $\mathrm{HH}$ : Economic impact of treatment of HIV-positive pregnant women and their newborns with zidovudine. JAMA 276:132-138, 1996. 


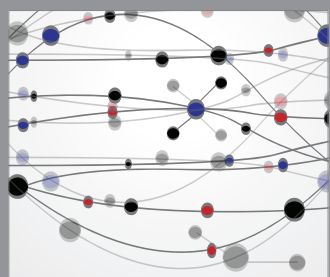

The Scientific World Journal
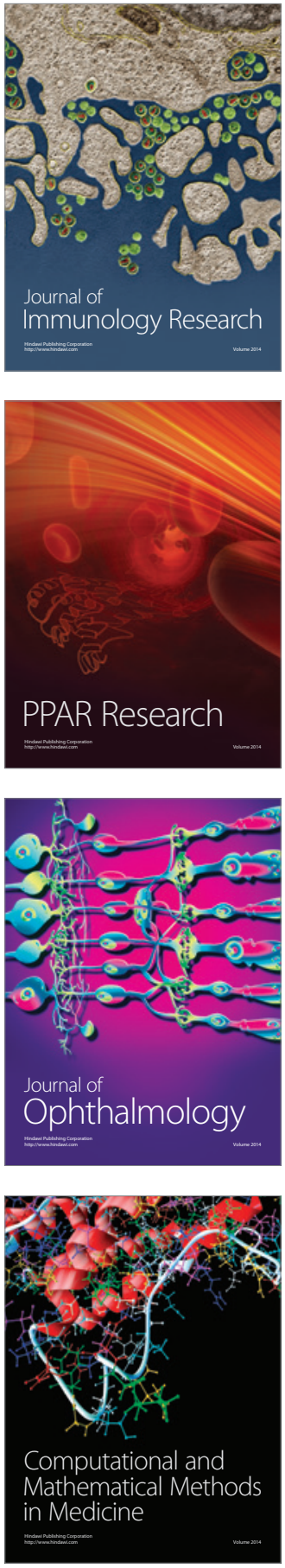

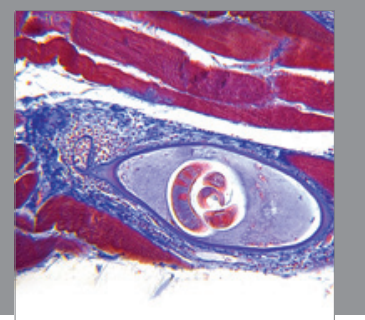

Gastroenterology

Research and Practice
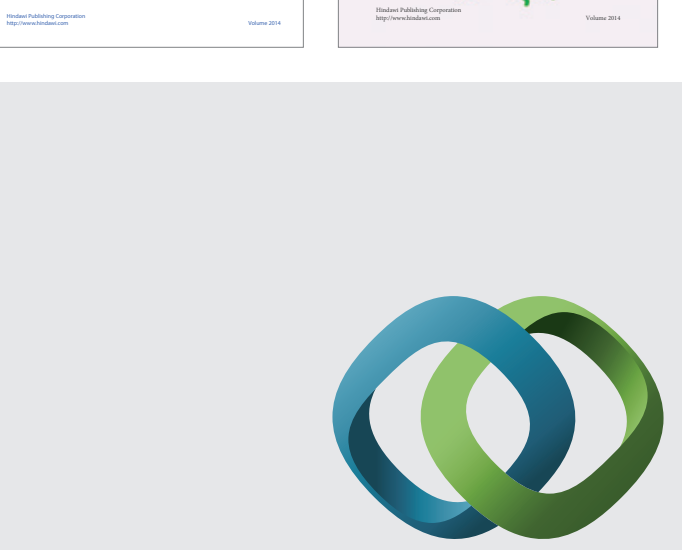

\section{Hindawi}

Submit your manuscripts at

http://www.hindawi.com
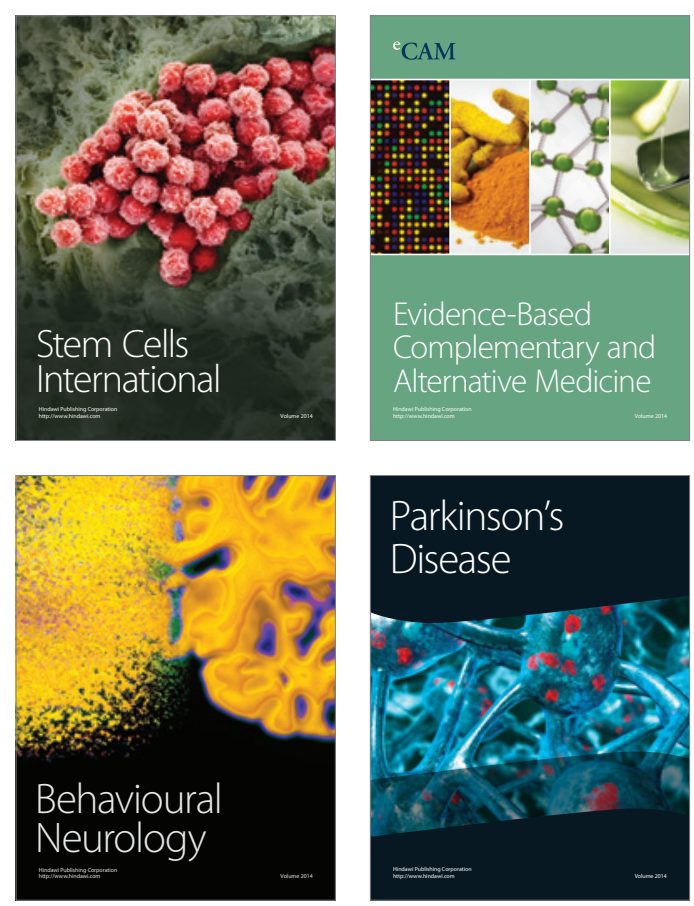

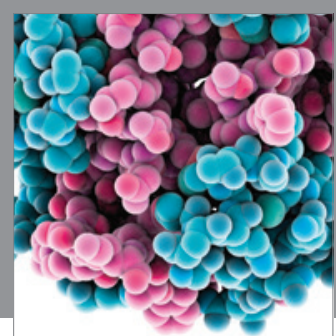

Journal of
Diabetes Research

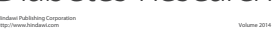

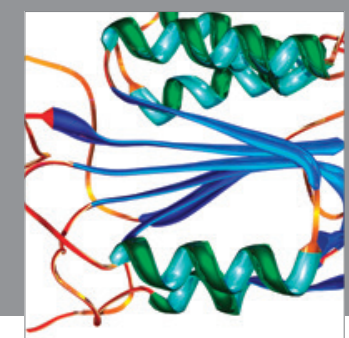

Disease Markers
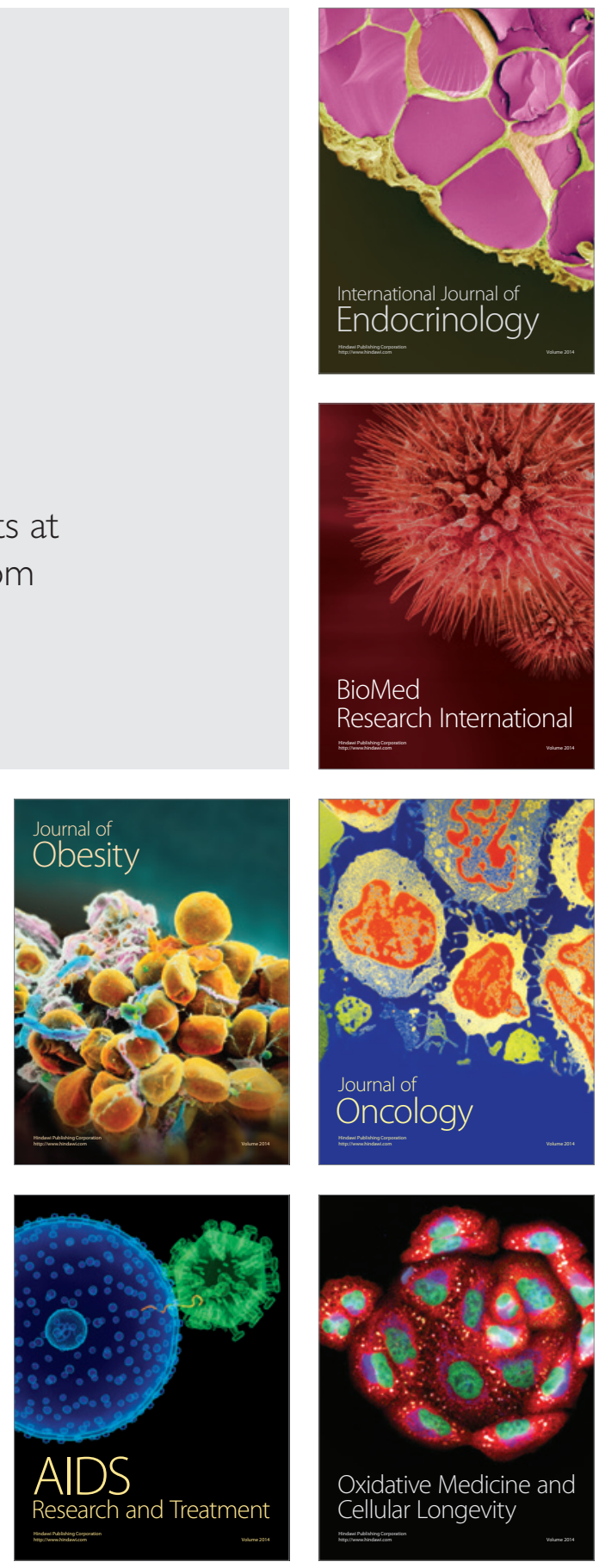